DOI : $10.14746 /$ ps.2018.1.34

\title{
Current Challenges for the Application of the Rule of Law in European States, Poznań, 12-13 April, 2018
}

More recently, a few European states have been alleged to have violated the rule of law, the key element of operation of a democratic state. Respect for the rule of law in European Union Member States has increasingly been of interest for EU institutions, both in relation to the procedure under Art. 7 of the Treaty of the European Union and to the proposal of the European Commission to link the amount of EU budget allocation for a Member State with the evaluation of the State's respect for the values enshrined in Art. 2 of the Treaty of the European Union, including the rule of law principle.

A significant role in both cases is played by the evaluation performed by the European Commission, the executive body in the institutional order of the EU. The unique function of the European Commission, coupled with laconic provisions of EU treaties and the fact that the rule of law was introduced into treaties only in 1999, along with the entry into force of the Amsterdam Treaty, triggers not only questions concerning the competence of the European Commission to audit the compliance of acts of national law with the rule of law principle, but first of all those concerning the normative content of the above principle, shared by all the EU Member States. The former question was addressed e.g. in the 2017 monograph by T. Konstadinides, The Rule of Law in European Union. The Internal Dimension, (Portland, Oregon, 2017). In the introduction the author observes: "Thus, despite its good will to enforce virtuous practice across the Member States by first extending EU law compliance outside cross-border situation and beyond mere breaches of substantive provisions, the EU has entered uncharted territory. Such a development may in turn expose the EU's power limits as well as democratic and rule of law flaws, viz the restrictive interpretation for entire system of the judicial review of EU law and externally viz the EU's international responsibility for wrongful acts with regard to, for instance, the implementation of various 'anti-crises' measures" (Ibid.: 4). As to the latter issue, which was the root cause of the organisation of the conference, one may quote A. v. Bogdandy's statement about difficulties with a definition of the normative content of the rule of law: "Dies ist kein leichtes Unterfangen, bildet doch die Rechtsstaatlichkeit ein nur schwer definierbares Konzept. Zudem verstehen die verschiedenen Verfassungstraditionen unter den englischen, griechischen, italienischen, französischen Entsprechungen rule of law,

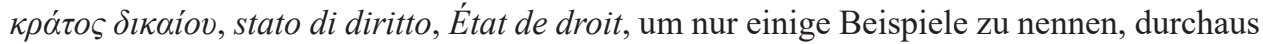
nicht immer dasselbe."

In the face of the above challenges, the Institute for Western Affairs (Instytut Zachodni, hereinafter IZ) decided to host an international conference dedicated to Current Challenges for the Application of the Rule of Law in European States. Conference participants included

${ }^{1}$ A. v. Bogdandy, M. Ioannidis (2014), Das systemische Defizit Merkmale, Instrumente und Probleme am Beispiel der Rechtsstaatlichkeit und des neuen Rechtsstaatlichkeitsaufsichtsverfahrens, „Zeitschrift für ausländisches öffentliches Recht und Völkerrecht“, No. 74, p. 288 ff. 
a number of specialists on constitutional law from Austria, Spain, Poland, Federal Republic of Germany, Hungary, and the representation of the European Commission in Poland. All of them look into the application of the rule of law in both theory and practice.

The first panel, titled Structural Issue of the Use of the Rule of Law in a Democratic State, held on 12 April 2018 in the IZ offices, addressed from the point of view of legal theory e.g.: the question of the normative content of the rule of law, first of all from the perspective of national jurisprudence, the interdependencies between the rule of law, the principle of sovereignty of a nation and that of the tripartite division of powers, with emphasis on the current problems arising from the use of the above principles in EU states. The panellists focused moreover on the activities of constitutional courts, with consideration of the unique characteristics of case law, so-called judicial law, and the democratic legitimacy of justices of constitutional courts to interpret the law. The panellists of the 1st panel were: a justice of the Federal Constitutional Court of the Federal Republic of Germany Peter Müller, who spoke about Gewaltenteilung und unabhängige Gerichtsbarkeit als Voraussetzung demokratischer Verfassungsstaatlichkeit (Division of power and independent jurisdiction as a condition for a democratic constitutional statehood), Prof. A. Bryk from Jagiellonian University, who spoke about the Sources and Consequences of the New Constitutionalism, Prof. C. Jabloner from the University of Vienna, for 20 years President of the Austrian Administrative Court, who spoke about Der Rechtsstaat zwischen Perfektionierung und Destruktion (State of Rule of Law - Between Perfectionism and Destruction), and Prof. A. Dziadzio from Jagiellonian University, with the lecture titled Dispute on the Essence of the Rule of Law in Historical and Present Context.

The well-researched presentations, which however demonstrated divergent approaches to the content and function of the rule of law and its relations to other systemic principles as well as on the role of constitutional courts in contemporary democratic systems, triggered a lively debate between the panel experts themselves and between them and the other conference participants.

The debate raised e.g. the following statements made in the presentations: "Concepts attempting to counter democracy and the rule of law are incompatible with the principles enshrined in the European treatises. This occurs when the term 'non-liberal democracy' is used to put forward a claim that the realisation of a uniform and objective will of the Nation has the highest priority in the democratic system" (P. Müller). "The rule of law principle does not give a guarantee of respect for itself but is invariably exposed to eternal elements. This is the theoretical core of the famous, if contentious and overused observation made by Böckenförde, who stated that 'A free secular state is sustained through the conditions it cannot guarantee of itself" (C. Jabloner). "The hierarchical structure of legal norms is today seen as the sole guarantee of the rights of the individual. All powers, including the legislator, have the role of "agendas of legal order," guarded by the constitutional court. Each attempt to change the position in the system of the constitutional court is considered as a threat to democracy, rule of law and the rights of the individual. "A sovereign democracy," where the nation as a political community makes use of the law to pursue their goals and interests, has been at present replaced by the "non-sovereign constitutional democracy" (A. Dziadzio).

During the second panel, Selected Issues of the Use of the Rule of Law Principle in a Multicentric Legal System were discussed apart from the above aspects of the rule of law in the European Union Member States. During this very panel, Mr. Rafał Szydlauer, coun- 
cillor for political and legal affairs in the Representation of the European Commission in Poland, delivered a lecture titled Dialogue Concerning the Rule of Law Principle Between Poland and the European Commission. He gave a succinct overview of the contention between the European Commission and the Government of the Republic of Poland concerning the reform of Polish judiciary. The debate on the one hand focused on the unambiguously negative assessment of Poland's current government coalition by the representative of the European Commission, and on the other hand the competence of the Commission to carry out assessment of the compliance with the Constitution of the Republic of Poland of the amendments introduced in said legislation. The procedure under Art. 7 TEU applies to the violation of values under Art. 2 TEU, the rule of law included. According to R. Szyndlauer's assumptions, the Commission assesses the violation of the principle by making use not of the criteria of EU law, but rather checking the compliance with the national constitution, thereby supplanting the national constitutional court. A question arises, then, if the procedure under Art. 7 TEU and the audit by the European Commission carried out under it, is a solution of the dilemma flagged by G. Jellinek in the 19th c. in the context of operation of a constitutional court: Quis custodiet custodes Ipsos? ${ }^{2}$ (Who will guard the guards themselves?)?

In reference to A. von Bogdandy's afore-quoted opinion about the ambiguity of the rule of law in the multicentric system of European law, and to R. Szyndlauer's statement, M. Bainczyk, senior analyst of the Institute for Western Affairs, delivered a presentation titled: Cztery wymiary zasady państwa prawnego w UE. Zasada państwa prawnego jako warunek członkostwa państwa w Unii Europejskiej w orzecznictwie polskiego i niemieckiego Trybunatu Konstytucyjnego (Four dimensions of the rule of law in the EU. The rule of law principle as a precondition for membership in the European Union in case law of the Polish and German Constitutional Court) ${ }^{3}$. In the speaker's opinion, the problem of defining at the EU level of the content of the rule of law principle and of the criteria of its violation may stem not only from its diverse understanding in various European states, but also from the divergent functions the principle plays in the multicentric system of European law. As of the 1970s, the rule of law enshrined in Art. 20 of the Basic Law of the Federal Republic of Germany was interpreted in the case law of the Federal Constitutional Court of the Federal Republic of Germany as an inviolable principle of this state's operation in the process of European integration, an element of the inviolable constitutional identity of Germany. In Poland, too, after its accession to the EU, Polish Constitutional Court referred to the rule of law as a precondition for Poland's integration with the EU. It was only in the late 1990s that the principle of the rule of law was introduced as an underlying principle to EU law, addressed to the EU as such (second dimension), its Member States (third dimension) and third countries (fourth dimension).

The next two presentations within the second panel related to questions of applying the rule of law in Spain and Hungary. Prof. A. Torres Gutiérrez from the University of Navarra delivered a lecture titled Contemporary Challenges for the Application of the Rule of Law in Spain. Following a brief historical and theoretical introduction to the provisions of the Spanish Constitution, A. Torres Gutiérrez discussed four extremely interesting cases where the use of the rule of law proved a substantial challenge for the judiciary, especially for the

${ }^{2}$ G.Jellinek (1885), Ein Verfassungsgerichtshof für Österreich, Wien, p. 25.

3 The presentation was partly based on conclusions derived from the research project number DEC-2012/05/B/HS5/01395 financed by NCN. 
Constitutional Court: 1) The limitation of the fundamental rights of the air traffic controllers, on the occasion of their strike of 3 December 2010,2) The abusive participation of executive power in the legislative process, 3) The appointment of State Public Prosecutor by the Government, and the separation of powers, 4) The secessionist tensions in Catalonia. In reference to the last case, A. Torres Gutiérrez concluded as follows: "We think that it is necessary to make two final reflections. The first one is that federalism is based on solidarity and constitutional loyalty. The second one is that this problem will not be resolved (only) with the application of the Criminal Code. It will be necessary to re-establish the political dialogue, and the Rule of Law."

In turn, Prof. G. Schweitzer from the Hungarian Academy of Science presented an overview of the application of the principle of rule of law in Hungary after the amendment of a law concerning the freedom of religion. The topic of his lecture was: The Legal Status of Churches and Religious Communities in Hungary Since 2011. Act IV of 1990 on the Freedom of Conscience and Religion and the Church on the one hand, under international norms guaranteed individual and collective entitlements, and, on the other hand, liberalized the procedure of founding churches. Starting 2011, the legislator tightened the conditions for the recognition of churches and many religious communities with church status were deprived of their status legally acquired previously. According to the legislator, the extremely generous conditions of founding a church gave opportunity for the abuse of law, and to undue access to state subsidies provided to churches, as well as for the registration of organizations as churches that in fact do not engage in religious activities. The above amendments were addressed in the 2014 judgement of the European Court of Human Rights (hereinafter ECHR) concerning the case of the Hungarian Christian Mennonite Church vs. Hungary ${ }^{4}$. ECHR indicated that Hungary is in breach of Art. 11 read in the light of Art. 9 of the European Convention on Human Rights and Fundamental Freedoms and found "that the Hungarian Government had not shown that there were not any other, less drastic solutions to problems relating to the abuse of State subsidies by certain churches than to de-register the applicant communities. Furthermore, it was inconsistent with the State's duty of neutrality in religious matters that religious groups had to apply to Parliament to obtain re-registration as churches and that they were treated differently from incorporated churches with regard to material benefits without any objective grounds"s. In the speaker's opinion, to date Hungary has failed to implement the above ECHR judgement.

This report indicates only some of the questions addressed during the two-day conference. Full texts of the presentations will be published as conference proceedings. The lively debate confirmed the significance and necessity of a dialogue between various European intellectuals, an element of building a European constitutional community. An interesting example of this debate is the agenda of the conference held by the German Forum of the History of the Judiciary (Forum Justizgeschichte e.V.): Unabhängige Justiz? Traditionen deustcher und europäischer Justizverwaltung (Independent Judiciary? German and European Traditions of Judicial Administration). The conference agenda implies that a reform of the judiciary is necessary in the Federal Republic of Germany, as the courts there operate on the basis of the 1935 law which currently, mainly with respect to court administra-

4 Judgement of ECHR, 8.04.2014, Magyar Keresztény Mennonita Egyház and Others v. Hungary 2 70945/11, 23611/12, 26998/12 et al.

${ }^{5}$ Freedom of religion, Factsheet, https://www.echr.coe.int/Documents/FS_Freedom_religion_ ENG.pdf (30.05.2018). 
tion, does not comply with European standards, and the principles of operation of German courts, including judicial appointments, even in the highest courts, are used as an argument by the Polish side.

Last but not least, we should point out that the speakers' lectures and the debate between the panellists and the other conference participants were translated simultaneously into Polish, German and English. In the unanimous opinion of conference participants, despite the highly specialised language and lively debates, the interpretation provided was of premium quality.

Magdalena BAINCZYK

Poznań 